\title{
Engels's Emergentist Dialectics
}

\section{KAAN KANGAL}

For varied reasons and on various occasions, contemporary natural scientists and philosophers, Marxist and non-Marxist alike, have expressed their admiration for Frederick Engels, the cofounder of dialectical materialism and scientific socialism.

Ilya Prigogine, winner of the 1977 Nobel Prize in Chemistry, wrote that the "idea of a history of nature as an integral part of materialism was asserted by [Karl] Marx and, in greater detail, by Engels." Modern developments in natural sciences have raised philosophical issues that dialectical materialists have long investigated. When Engels was working on his Dialectics of Nature in the 1870s and ' 80 s, there was a visible tendency on the rise in the natural sciences that "rejected the mechanistic world view," drawing "closer to the idea of an historical development of nature." Engels contributed to making explicit what was already implicit in the natural sciences of his time. Now as then, the natural sciences are occupied with the question of "how can the world of processes and the world of trajectories ever be linked together." Engels may have not brought his work in progress to completion, but what he left behind continues to help enrich our philosophical understanding of nature and improve our orientation to the natural sciences of our time. ${ }^{1}$

In his 1939 preface to the first English edition of Dialectics of Nature, biologist J. B. S. Haldane wrote that Engels's contributions to the philosophy of nature and the natural sciences are widely known from his Anti-Dühring. However, Engels's more comprehensive Dialectics of Nature was rather recently, in the 1920s, discovered and published. "Had Engels' method of thinking been more familiar, the transformations of our ideas on physics which have occurred during the last thirty years would have been smoother. Had his remarks on Darwinism been generally known, I for one would have been saved a certain amount of muddled thinking." ${ }^{2}$

Commenting on Engels's 1876 essay from Dialectics of Nature entitled "The Part Played by Labor in the Transition from Ape to Man," paleontologist Stephen Jay Gould wrote that Engels provided us with a "brilliant exposé" of an advanced theory of human evolution with the role of labor at its heart. Gould was particularly impressed by Engels's view that the human

KAAN KANGAL is an associate professor of philosophy at Nanjing University, specializing in dialectics, hermeneutics, metaphysics, and Marx-Engels research. His work on Marx's Bonn Notebooks won the 2019 David Riazanov Prize. His most recent publication is Friedrich Engels and the Dialectics of Nature (Palgrave Macmillan, 2020). 
"hand is not only the organ of labor, it is also the product of labor.... As humans learned to master their material surroundings, Engels argues, other skills were added to primitive hunting - agriculture, spinning, pottery, navigation, arts and sciences, law and politics." ${ }^{3}$ Elsewhere, Gould asserted that all human evolution stands and falls with gene-culture coevolution and "the best nineteenth-century case for gene-culture coevolution was made by Friedrich Engels in his remarkable essay of 1876."

Though not a Marxist himself, the evolutionary biologist Ernst Mayr found that his own philosophical conception of biology has surprisingly much in common with the principles of dialectical materialism. His short piece "Roots of Dialectical Materialism" opens with a short anecdote of Mark Adams, a U.S. historian of biology who went to the Soviet Union to conduct interviews with various scientists, including Kirill M. Zavadsky. During the interview, Zavadsky asked: “'Do you know Ernst Mayr?' / Adams: 'Yes, very well.' / Zavadsky: 'Is he a Marxist?' / Adams: 'He is not, so far as I know.' / Zavadsky: 'This is very curious because his writings are pure dialectical materialism.'” Initially puzzled by Zavadsky's comment, Mayr came later to the conclusion that he was actually a proponent of dialectical-materialist principles such as processuality, universal interconnection, and perpetual change in nature. "It is not known how many, perhaps most, of these principles were arrived at independently by natural history and dialectical materialism.... Dialectical materialism was for Engels and Marx a general philosophy of nature. It was achieved primarily by an elimination of physicalism and Cartesianism.... It is necessary to develop the characteristics and principles of the various 'provincial' sciences, such as physics and biology, in order to construct eventually a comprehensive Philosophy of Nature, which does equal justice to all sciences."

In a similar vein, the British biochemist and sinologist Joseph Needham drew attention to Engels's conviction that "nature is through and through dialectical" and that Engels correctly directed his dialectics against

the static conceptions of the scientists of his time, who were unprepared for the mass of contradictions that science was about to have to deal with, and who did not appreciate that Nature is full of apparently irreconcilable antagonisms and distinctions which are reconciled at higher organizational levels. The well-known rules of the passing of quantity into quality, the unity of opposites and the negation of negations, have all become commonplaces of scientific thought. ${ }^{6}$

Mario Bunge, an Argentinian philosopher of science, is well-known for his hostility toward Engels's dialectics and dialectical materialism. Both in public and private, Bunge made no secret of his stance. In an encounter with Soviet Marxist philosopher Bonifaty M. Kedrov, the old issue of dialec- 
tics came up. "The applied mathematician Mircea Malitza...invited us to a party in his flat along with Tarski, Kedrov, and others. When I told Kedrov that one of my discrepancies with Marxism was that I rejected dialectics," Kedrov ironically replied: "Don't worry, tovarich Bunge, for Marx mentions dialectics only six times in his Kapital." Yet, in some respect, Bunge gave credit to Marxist philosophy, as he admitted that "dialectics has taught us to mistrust stillness, for it may hide struggle, and equilibrium, for it may be unstable. It has also taught us that not all strife is bad: some may result in new and better things." "The plausible kernel of dialectics is constituted by the hypotheses (i) that every thing is in some process of change or other, and (ii) that at certain points in any process new qualities emerge." Elsewhere, he praised Engels's insistence on incorporating G. W. F. Hegel's method, rather than his system, into dialectical materialism. ${ }^{10}$

That Engels the autodidact polymath continues to inspire later generations of philosophers and natural scientists in one way or another is self-evidently accompanied by the fact that the research material Engels made use of is largely incomplete and dated. When preparing Marx and Engels's writings for publication back in the early 1920s, Eduard Bernstein ran into the problem of whether Engels's Dialectics of Nature was worth publishing. He asked Albert Einstein for his opinion. Einstein said that the manuscripts have no merit from the angle of contemporary physics, but that they certainly provide interesting insights into Engels's intellectual biography. ${ }^{11} \mathrm{To}$ name another example, Richard Lewontin and Richard Levins's The Dialectical Biologist came out with this dedication: "To Frederick Engels, who got it wrong a lot of time but who got it right where it counted."12 Finally, analytical philosopher Hilary Putnam similarly pointed out the following: "I think Engels was one of the most scientifically learned men of his century. He got a number of things wrong, but he had an immense general scientific knowledge, and Anti-Dühring, his big book on philosophy of science...is, in many ways, a sensible book on philosophy of science, among other things." ${ }^{13}$

It is an irony indeed that Engels foresaw much of the future consequences of those sections of his work that required further elaboration. In this regard, he wrote in the second preface to Anti-Dühring that

there is much that is clumsy in my exposition and much of it could be expressed today in a clearer and more definite form.... The advance of theoretical natural science may possibly make my work to a great extent or even altogether superfluous. For the revolution which is being forced on theoretical natural science by the mere need to set in order the purely empirical discoveries, great masses of which have been piled up, is of such a kind that it must bring the dialectical character of natural processes more and more to the consciousness even of those empiricists who are most opposed to it. ${ }^{14}$ 
Looking back at the massive achievements of this intellectual giant from our present standpoint, the primary question that should concern us is: What is indispensable, rather than superfluous, in Engels's work on philosophy and natural sciences? Scholars from diverse backgrounds invariably agree that the emergentist character of Engels's dialectics stands out.

For instance, Polish historian Zbigniew A. Jordan forcefully argued that "the central idea of emergent evolution is to be found in Anti-Dühring and Dialectics of Nature." According to Engels's emergentist dialectics, "material reality has a multilevel structure; each of these levels is characterized by a set of distinctive properties and irreducible laws; and each level has emerged from temporally prior levels according to laws which are absolutely unpredictable with respect to those operating at the lower levels." The idea of emergence is intimately tied to Engels's conception of dialectics as the science of interconnections between coexisting and interdependent systems of physical bodies. Engels's famous dictum that motion is the mode of existence of matter suggests that matter has the power to generate novelty and diversity in nature. The principle that "matter is capable of creating novelty and of producing higher and higher forms of organization has been part and parcel of dialectical materialism ever since it was first formulated by Engels." ${ }^{15}$ As the Scottish mathematician and philosopher Hyman Levy aptly formulated, the dialectical idea of evolution suggests that "complex forms of living animal and vegetable matter have emerged from simpler forms that link on through almost countless ages back to more and more elementary forms." ${ }^{16}$

Even Bunge shares the belief that "dialectical materialism has the merit of emphasizing qualitative novelty, or emergence," or what Mayr called "a hierarchy of levels of organization, at each of which a different set of dialectical processes may be at work." ${ }^{17}$ Since different levels of complexity of motion constitute a hierarchy of levels of organization of matter, as Ted Benton observes, nature needs to be considered a hierarchically ordered and internally differentiated unity. It is this unity that figures as the precondition for the convergence of particular sciences. Unified knowledge of nature presumes an interconnected unity of differentiated and uneven historical development of discrete sciences. "The domain of nature with which each science deals represents not only a distinct level of complexity of motion, but also a definite stage in the historical evolution of the universe ${ }^{\prime 18}$

Put differently, it is the historicity of nature as well as the ongoing progress in particular sciences that necessitate a critical revision of our scientific framework. There is always a theory-internal need to examine rigorously the conceptual apparatus in use. This also implies a continuous integration of newly emerged and discovered novelties into our present body of thought. Therefore, it comes as no surprise that Engels's dialectics is large- 
ly concerned with evolving interconnections and emerging novelties in nature. Relatedly, Engels defines dialectics as the systematic inquiry into universal interconnections in nature: "It is precisely dialectics that constitutes the most important form of thinking for present-day natural science, for it alone offers the analogue for, and thereby the method of explaining, the evolutionary processes occurring in nature, inter-connections in general, and transitions from one field of investigation to another."19

In grasping emergent qualities and laws on various levels of organization of matter, dialectical theory employs its own conceptual structure, scientific language, and investigation method, and takes a categorially open-ended shape.

In a passage where Engels discusses some criteria for distinguishing and classifying various scientific disciplines, he underlines that each science occupies itself with a specific form of motion peculiar to the corresponding terrain. The subject matter of analysis might be "a single form of motion or a series of forms of motion that belong together and pass into one another." ${ }^{20}$ The point is that such a classification needs to follow the objective arrangement and inherent developmental sequence of the forms of motion in question. It goes without saying that the logical-ontological reconstruction of the sequence of natural events must take a systematic shape, accordingly. "If I term first of all physics the mechanics of molecules, chemistry the physics of atoms, and furthermore biology the chemistry of proteins, I wish thereby to express the passing of each of these sciences into another, hence both the connection, the continuity, and the distinction, the discrete separation." ${ }^{21}$

When the organic world grows out of the inorganic, it develops specific forms of movement and its own special laws. What historically precedes the development of the organic world, that is, the inorganic, lives on in a "sublated" form..$^{22}$ Yet, the organic world is evidently different from the inorganic. Its system possesses many emergent properties never found in the inorganic world. Most crucially, behavioral patterns of organic systems are governed by their genetic programs that contain historically acquired information. ${ }^{23}$

In this context, Engels provides a remarkable illustration that not only argues for the interconnection and interpenetration of distinct spheres such as chemistry and biology, but also draws on an emergent property that is nowadays called autopoiesis, a generative feature of self-organizing systems:

In the organic world....all chemical investigations lead back in the last resort to a body - protein - which, while being the result of ordinary chemical processes, is distinguished from all others by being a self-acting, permanent chemical process. If chemistry succeeds in preparing this protein, in the specific form in which it obviously arose, that of a so-called protoplasm, a 
specificity, or rather absence of specificity, such that it contains potentially within itself all other forms of protein..., then the dialectical transition will have been proved in reality, hence completely proved. ${ }^{24}$

Emergentist dialectics defends the view of "continuous rise in level of organization" and complexity of systemic mechanisms in nature. Succession of each and every level depends on the material circumstances for the flowering of its emergent properties that are necessarily unique relative to the preceding levels of complexity. Provisionally, different levels can be distinguished from each other by means of their respective components. ${ }^{25}$ But they are properly differentiated if the interrelation and internal organization of the parts are taken into account. Quarks combine to form hadrons such as protons and neutrons, which in turn form atoms, which constitute molecules, which build up cell constituents and colloidal particles, colloidal aggregates give rise to tissues and living cells, and cells to organs and organ systems, and so on.

Friction produces heat, light, and electricity, impact produces heat and light if not electricity also - hence conversion of motion of masses into molecular motion. We enter the realm of molecular motion, physics, and investigate further. But here too we find that molecular motion does not represent the conclusion of the investigation. Electricity passes into and arises from chemical transformation. Heat and light, ditto. Molecular motion becomes transformed into motion of atoms - chemistry. The investigation of chemical processes is confronted by the organic world as a field for research, that is to say, a world in which chemical processes take place, although under different conditions. ${ }^{26}$

The higher level of complexity contains also those components from the lower level. However, the point of emergence is not simply what components are contained on what level but rather how those parts are interrelated to each other on specific levels of complexity. Subsequently, when assessing various interacting levels of complexity, the dialectical emergentist is at pains to integrate, and not juxtapose, parts of a whole in differentiated degrees of organization of matter. ${ }^{27}$

[The] organism is certainly the higher unity which within itself unites mechanics, physics, and chemistry into a whole where the trinity can no longer be separated. In the organism, mechanical motion is effected directly by physical and chemical change, in the form of nutrition, respiration, secretion, etc., just as much as pure muscular movement.... After the transition from chemistry to life has been made, then in the first place it is necessary to analyse the conditions in which life has been produced and continues to exist, i.e., first of all geology, meteorology, and the rest. Then the various forms of life themselves, which indeed without this are incomprehensible. ${ }^{28}$ 
The constituent parts of an encompassing whole acquire their integral status in that their properties come into existence by means of their interaction and interpenetration, which eventually bring about a specific mode of organization peculiar to the whole in question. ${ }^{29}$ Note here that parts do not come together in order to make a whole to which they belong. Rather, their very interaction structures the way they are interrelated and interpenetrated, resulting in what is called a whole. ${ }^{30}$

While the philosophical rival of emergentism - that is, reductionism, which claims that mechanisms of higher-level complexities are directly caused by lower-level dynamics - emergentism effectively resists the idea that the whole is "nothing but" the components contained within that whole. The whole is more than the total sum of its parts.

Lewontin and Levins carefully point out that there is a difference between reduction and reductionism. While it is true that the composition and structure of a lower level can figure as a "symptom of the forces acting at higher levels," this does not mean that the lower-level situation is also the immediate cause of the higher-level interaction. "Reduction looks to lower levels of analysis for differentiating symptoms of forces at higher levels, whereas reductionism claims that forces at lower levels are the actual causes of the phenomena higher up." 31 This is to say, because the low-level composition may codetermine the form within which the interaction of high-level organization of matter takes place, what co-contributes to the formation of higher-level phenomena can be traced back to their low-level predecessors. In any case, low-level and high-level phenomena are by no means linked by immediate causality. Rather, they are intermediated by Hegelian "nodal points."

At some point, Engels contrasts higher and more complex forms of motion with subsidiary forms. He observes that some scientists of his time give an exhaustive weight to motion that is accompanied by a "craze to reduce everything to mechanical motion." Such a treatment of motion "obliterates the specific character of other forms of motion." Relatedly, the overt focus on mechanical motion misses that "higher forms of motion" are "connected with some real mechanical (external or molecular) motion" and that "the higher forms of motion simultaneously also produce other forms." This ultimately leads to the ignorance of variety and species of motion and interconnection in nature. However, "chemical action is not possible without change of temperature and electric changes, organic life without mechanical, molecular, chemical, thermal, electric, etc., changes." One form of motion is manifested within another, as both interpenetrate each other. From the angle of the organizing center of a particular material sphere of motion, a distinction has to be made between main and subsidiary forms. "But the presence of these subsidiary forms does not 
exhaust the essence of the main forms in each case. One day we shall certainly 'reduce' thought experimentally to molecular and chemical motion in the brain; but does that exhaust the essence of thought?"32

These lines make clear that Engels conceived of the lower-level elements as the historical constituents of the newly emerged higher-level organization of matter. Engels agreed that the present forms of motion can be traced back to their past developmental record (reduction), but denied that higher-level emergent properties can be explained solely by the lower-level properties from which they emerge (reductionism).

It is also important to keep in mind that it was a reductionist trend in philosophy and theoretical natural sciences in the second half of the nineteenth century that initially motivated Engels to offer an alternative account. In the beginning of the 1870s, Engels planned to write a concise response to contemporary reductionist materialist views such as Ludwig Büchner's dualistic ontology of physical matter and force, or Carl Vogt and Jacob Moleschott's crude reduction of human thinking to brain substance or phosphorus fat. But Engels's early planned attacks turned later on into a more or less systematic undertaking (Dialectics of Nature) when Darwin's theory of evolution was quickly politicized both in socialist and reactionary liberal literature. Alerted first by the Paris Commune of 1871, then the economic crisis in 1873, and finally the parliamentary success of the Social Democratic Party in 1877, reactionary biologists such as Rudolf Virchow, Oscar Schmidt, and Ernst Haeckel tried to weaken the socialist reception of Darwinism. Most forcefully, Haeckel tried to keep the social Darwinist idea intact by arguing that the rules of the animal kingdom fully apply to humankind.

While all the aforementioned figures were on the "hit list" of Dialectics of Nature, Engels was also aware of, and prepared himself to respond to, other debates that joined the reductionist controversies. One such issue was a vivid positivist tendency advocated by figures such as the neo-Kantian biologist Matthias Schleiden who openly attacked Hegelian philosophy and the materialist worldview against which Rudolf Virchow and Haeckel were completely defenseless. Another crucial issue that accompanied the ongoing disputes concerned the Ignorabimus account that was voiced primarily by the neo-Kantian botanist Carl Nägeli. With recourse to Kant's thing-in-itself, Nägeli asserted that infinity and the universality of natural laws remain a mystery, for only the finite domains of nature are accessible to the human mind. This much celebrated proposition was expressive of the neo-Kantian trend in the growing fragmentation of particular sciences and positivist hostility toward dialectical philosophies of nature. Other than the biological theories of cell and evolution, the thermodynamic laws of energy were also on Engels's agenda. As the manuscript fragments 
of the Dialectics of Nature from the early 1880s document, Engels shifted his attention to and was occupied mainly by the recent innovations in physics until Marx's death in 1883. Having discovered Marx's economic manuscripts, he had to interrupt his natural scientific inquiries once again and devote himself to preparing Marx's writings for publication instead.

Engels may not have left us a fully worked out philosophy of nature, but he left us the general outlines of a research program that is inevitably open ended and necessarily incomplete. In fact, he made quite clear that incompleteness and open-endedness are built in features of his program. One of the greatest merits of Engels's unfinished work is that it successfully demonstrates how the dialectical-materialist inheritance of the Hegelian legacy can help us navigate the questions we have yet to ask, problems we have yet to formulate, and terrains we have yet to explore. As far as I can see, dialectical materialism has only partially claimed its place in the most recent discussions on emergence and reductionism in the philosophy of science. ${ }^{33}$ Due to the constraints of this present piece, I am not able to develop a full argument, but will instead mention one or two ideas that underpin my intuition.

Incorporating several valuable aspects of the Hegelian heritage into Marxist philosophy, Engels cleared the way for establishing a dialectical-materialist ontology of emergence. He maintained the view that singular finite entities that compound the reality to which we belong have no veritable being without collective dependence and mutual interaction among each other. Resulting from their transformative evolution, finite parts combine to form an infinitely self-developing totality. Such finite parts count as components of the whole insofar as they codetermine and cocreate the internal relations weaving them together. Accordingly, a rigorous dialectical inquiry into the fundamental structures of reality needs to develop a self-critical awareness of its categorial framework, one that is open to perpetual remaking. Emergence of objective novelties and their subjective integration into the present body of thought are therefore not of peripheral but central concern. ${ }^{34}$ In the "Plan 1878" from Dialectics of Nature, Engels formulated this view very explicitly as the fourth dialectical law: "spiral form of development." 35

The most basic and simple idea underlying this law concerns the structural forms of how one thing emerges from another. Put roughly, when a set of entities brings about another set of things, the prior level contains the potential of what it gives rise to. What comes into view is the posterior manifestation of what precedes it.

One section in Hegel's Doctrine of Essence in his Logic that usually goes unnoticed - "Movement of Reflection" - provides further insights into the dialectical logic of emergence. This chapter contains passages highlighting what Hegel calls "positing," "external," and "determining reflection." The 
same threefold structure amounts to what he alternatively terms the binary of "reflection-into-itself" and "reflection-into-other." Though Hegel pursues there a pure logical investigation and employs a somewhat clumsy terminology, his guiding thread promises fertile ground for further elaboration of Engels's emergentist dialectics: when one thing brings about another thing (reflection-into-other), it is affected by what has emerged from it (reflection-into-itself). This is to say that one thing (positing reflection) becomes subject to change (determining reflection) by causing another thing to change (external reflection). Hence, the former becomes the coproduct of its own activity. This aspect of self-reference or self-organization is, I believe, at the heart of Engels's emergentist dialectics. And the emergent structures and autopoietic systems are proof of it.

\section{Notes}

1. Ilya Prigogine and Isabelle Stengers, 13. Bryan Magee, "The Philosophy of Order out of Chaos: Man's New Dialogue Science: Dialogue with Hilary Putnam," with Nature (Toronto: Bantam, 1984), in Men of Ideas: Some Creators of Con252-53. temporary Philosophy (London: British

2. J. B. S. Haldane, preface to Dialectics of Nature, by Frederick Engels (New York: International Publishers, 1940), xiv.

3. Stephen Jay Gould, Ever Since Darwin: Reflections in Natural History (New York: Norton, 1977), 210, 212.

4. Stephen Jay Gould, An Urchin in the Storm: Essays About Books and Ideas (New York: Norton, 1987), 111.

5. Ernst Mayr, "Roots of Dialectical Materialism," in Na Perelome: Sovetskaia biologia v 20-30kh godakh, ed. E. I. Kolchinskii (St. Petersburg: SPBF IIET RAN, 1997), 12-14, 17.

6. Joseph Needham, Time, the Refreshing River (London: George Allen, and Unwin, 1943), 190.

7. Mario Bunge, Between Two Worlds Memoirs of a Philosopher-Scientist (Switzerland: Springer, 2016), 231.

8. Mario Bunge, Philosophy in Crisis: The Need for Reconstruction (New York: Prometheus, 2001), 40.

9. Mario Bunge, Scientific Materialism (Dordrecht: D. Reidel, 1981), 41.

10. Mario Bunge, Evaluating Philosophies (Dordrecht: Springer, 2012), 4.

11. Albert Einstein, "Opinion on Engels' 'Dialectics of Nature,'" in The Collected Papers of Albert Einstein, vol. 14 (Princeton: Princeton University Press, 2015), 414.

12. Richard Levins and Richard Lewontin, The Dialectical Biologist (Cambridge, MA: Harvard University Press, 1985), v.

Broadcasting Corporation, 1978), 237.

14. Frederick Engels, Anti-Dühring, in Collected Works, vol. 25, by Karl Marx and Frederick Engels (Moscow: Progress, 1987), 11, 13.

15. Zbigniew A. Jordan, The Evolution of Dialectical Materialism: A Philosophical and Sociological Analysis (London: Macmillan, 1967), 166, 167, 239.

16. Hyman Levy, A Philosophy for a Modern Man (London: Victor Gollancz LTD, 1938), 28.

17. Mario Bunge, Emergence and Convergence: Qualitative Novelty and the Unity of Knowledge (Toronto: University of Toronto Press, 2003), 147; Mayr "Roots of Dialectical Materialism," 14.

18. Ted Benton, "Engels and the Politics of Nature," in Engels Today: A Centenary Appreciation, ed. Christopher J. Arthur (Hampshire: Macmillan, 1996), 87; Ted Benton, "Natural Science and Cultural Struggle: Engels on Philosophy and the Natural Sciences," in Issues in Marxist Philosophy, vol. 2, Materialism, ed. John Mepham and David-Hillel Ruben (New Jersey: Humanities Press, 1979), 124, 125.

19. Frederick Engels, Dialectics of $\mathrm{Na}$ ture, in Collected Works, vol. 25, by Karl Marx and Frederick Engels (Moscow: Progress Publishers, 1987), 339.

20. Engels, Dialectics of Nature, 528.

21. Engels, Dialectics of Nature, 531.
22. Nikolai I. Bukharin, "Marx's Teaching and Its Historical Importance," in Marxism and Modern Thought, by Nikolai I. Bukharin et al. (New York: Harcourt, 1935), 31.

23. Ernst Mayr, This Is Biology: The Science of the Living World (Cambridge: Belknap, 1998), 20-21.

24. Engels, Dialectics of Nature, 53435, emphasis added.

25. Needham, Time, the Refreshing River, 15, 184-85.

26. Engels, Dialectics of Nature, 534 .

27. Mayr, This Is Biology, 16, 18-20.

28. Engels, Dialectics of Nature, 529-30.

29. Levins and Lewontin, The Dialectical Biologist, 273.

30. Richard Lewontin and Richard Levins, Biology Under the Influence: Dialectical Essays on Ecology, Agriculture, and Health (New York: Monthly Review Press, 2007), 132.

31. Lewontin and Levins, Biology Under the Influence, 136.

32. Engels, Dialectics of Nature, 527.

33. For an insightful approach to the emergence-dialectics connection, see Poe Yu-ze Wan, "Dialectics, Complexity, and the Systemic Approach: Toward a Critical Reconciliation," Philosophy of the Social Sciences 43, no. 4 (2012): 411-52.

34. Kaan Kangal, Friedrich Engels and the Dialectics of Nature (Cham: Palgrave Macmillan, 2020), 157-65.

35. Engels, Dialectics of Nature, 313. 